\title{
Comparing Complete Mitochondrion Genome of Bloom-forming Macroalgae from the Southern Yellow Sea, China
}

\author{
Jing Xia ${ }^{1}$, Peimin $\mathrm{He}^{1}$, Jinlin Liu ${ }^{1, *}$, Wei Liu ${ }^{1}$, Yichao Tong ${ }^{1}$, Yuqing Sun ${ }^{1}$, Shuang Zhao ${ }^{1}$, Lihua Xia ${ }^{2}$, Yutao Qin ${ }^{2}$, Haofei \\ Zhang $^{2}$, and Jianheng Zhang ${ }^{1, *}$ \\ ${ }^{1}$ College of Marine Ecology and Environment, Shanghai Ocean University, Shanghai, China, 201306 \\ ${ }^{2}$ East China Sea Environmental Monitoring Center, State Oceanic Administration, Shanghai, China, 201206
}

\begin{abstract}
The green tide in the Southern Yellow Sea which has been erupting continuously for 14 years. Dominant species of the free-floating Ulva in the early stage of macroalgae bloom were Ulva compressa, Ulva flexuosa, Ulva prolifera, and Ulva linza along the coast of Jiangsu Province. In the present study, we carried out comparative studies on complete mitochondrion genomes of four kinds of bloom-forming green algae, and provided standard morphological characteristic pictures of these Ulva species. The maximum likelihood phylogenetic analysis showed that $U$. linza is the closest sister species of $U$. prolifera. This study will be helpful in studying the genetic diversity and identification of Ulva species.
\end{abstract}

\section{Introduction}

Green tides, which occur widely in many coastal areas, are caused primarily by flotation, accumulation, and excessive proliferation of green macroalgae, especially the members of the genus Ulva [1-3]. China has the high frequency outbreak of the green tide [4-10]. Especially, the world's largest green tide events, have occurred annually from 2007 to 2020 along the coast of the Yellow Sea, China, seriously affecting marine environments and ecological services functions [11-15].

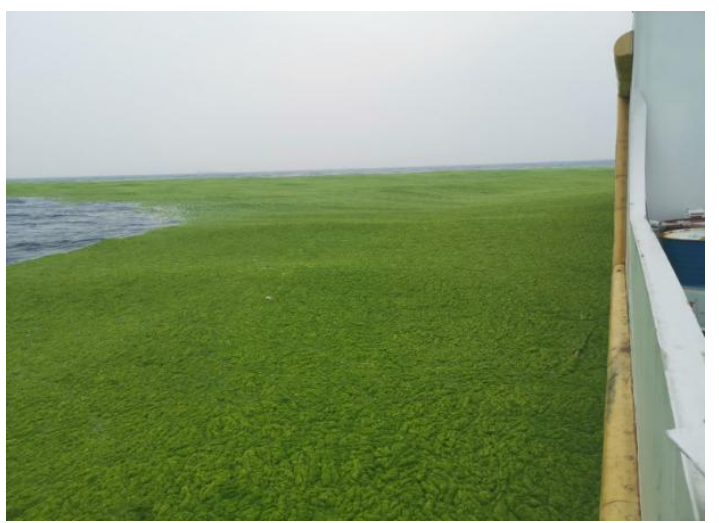

Figure 1. Green tide outbroke in the Southern Yellow Sea On June 18, 2019.

An interesting phenomenon called Ulva species succession were found at the early stage of the blooms in the Southern Yellow Sea. The initial floating species was identified as Ulva compressa; Ulva flexuosa and Ulva linza were the second floating species; and Ulva prolifera was the last [16-18]. However, during the drifting process of the blooms, $U$. prolifera became the dominant species and other species disappeared

*Corresponding authors: 15721539745@139.com (Jinlin Liu); jh-zhang@shou.edu.cn (Jianheng Zhang) gradually [19]. Thus, it was meaningful to carry out comparative studies on organelle genomes of these bloom-forming green algae.

\section{The specimen and data preparation}

In our previous studies, mitochondrion genome of $U$. flexuosa (NC035809; KX455878) [20], U. linza (NC029701; KU189740) [21], U. compressa (KX595276), and $U$. prolifera (KU161104) were conducted [22]. We downloaded these sequences from US National Center for Biotechnology Information (NCBI: www.ncbi.nlm.nih.gov/) (Table 1). A total of 6 complete mitochondrion genome of Ulva and 1 outgroup called Pseudendoclonium akinetum (AY359242) were used during this study.

Table 1. Detailed information on the samples used for genetic analysis collected from NCBI database.

\begin{tabular}{|c|c|c|c|}
\hline Species & $\begin{array}{c}\text { GenBank } \\
\text { information }\end{array}$ & $\begin{array}{c}\text { Sequence } \\
\text { length/bp }\end{array}$ & $\begin{array}{c}\text { Specimen } \\
\text { location }\end{array}$ \\
\hline U. flexuosa & $\begin{array}{c}\text { NC035809K } \\
\text { X455878 }\end{array}$ & $\begin{array}{c}71,545 \\
71,545\end{array}$ & $\begin{array}{c}\text { SHOUM, } \\
\text { China }\end{array}$ \\
\hline U. linza & NC029701K & 70,858 & $\begin{array}{c}\text { SHOUM, } \\
\text { China }\end{array}$ \\
\hline U. compressa & KX595276 & 62,311 & $\begin{array}{c}\text { SHOUM, } \\
\text { China }\end{array}$ \\
\hline U. prolifera & KU161104 & 61,962 & $\begin{array}{c}\text { SHOUM, } \\
\text { China }\end{array}$ \\
\hline
\end{tabular}

Also, specimens were stored in the herbarium of Shanghai Ocean University Museum (SHOUM). Based on these four kinds of Ulva specimens, we took clear 
morphological photographs by using the camera model GE-X2600.

\section{Result and discussion}

A Maximum-likelihood (ML) phylogenetic tree with 6 complete mitochondrion genome of Ulva and 1 outgroup called P. akinetum (AY359242) was constructed by using the MEGA 7 software (Figure 2) [21-22], which showed $U$. prolifera is closely related to $U$. linza. In addition, the standard morphological characteristics of these Ulva species were presented in Figure 2.

The formation of the green tide in the Southern Yellow Sea of China is complicated. Many researches demonstrated that the significant amount of attached Ulva species on the Pyropia aquaculture rafts were considered as the main source of the blooms in the Southern Yellow Sea [23-25]. The attached Ulva species consisted of four species which were $U$. compressa, $U$. linza, U. flexuosa and U. prolifera. During the harvest season of Pyropia aquaculture, as a kind of fouling macroalgae, the attached Ulva were removed artificially, resulting in the initial formation of the blooms.

These four kinds of Ulva species could be distinct from the complete mitochondrion genomes (Figure 2). Also, the morphological characteristics of these bloomforming species are different during the initial formation of the bloom process (Figure 2), and in conbine with these methods above, we can distinguish the Ulva species.

The largest green tide bloom areas in the Southern Yellow Sea of China from 2007 to 2019 was shown in Figure 3. China has the high frequency outbreak of the green tide, in 2009, the cover area of green tide outbreaks in the Southern Yellow Sea of China has reached 2,100 km² (Figure 3) [26-28]. Maybe through the application of biological prevention, strengthening breeding management and other methods, we can fundamentally solve the problem of green tides [29-30].

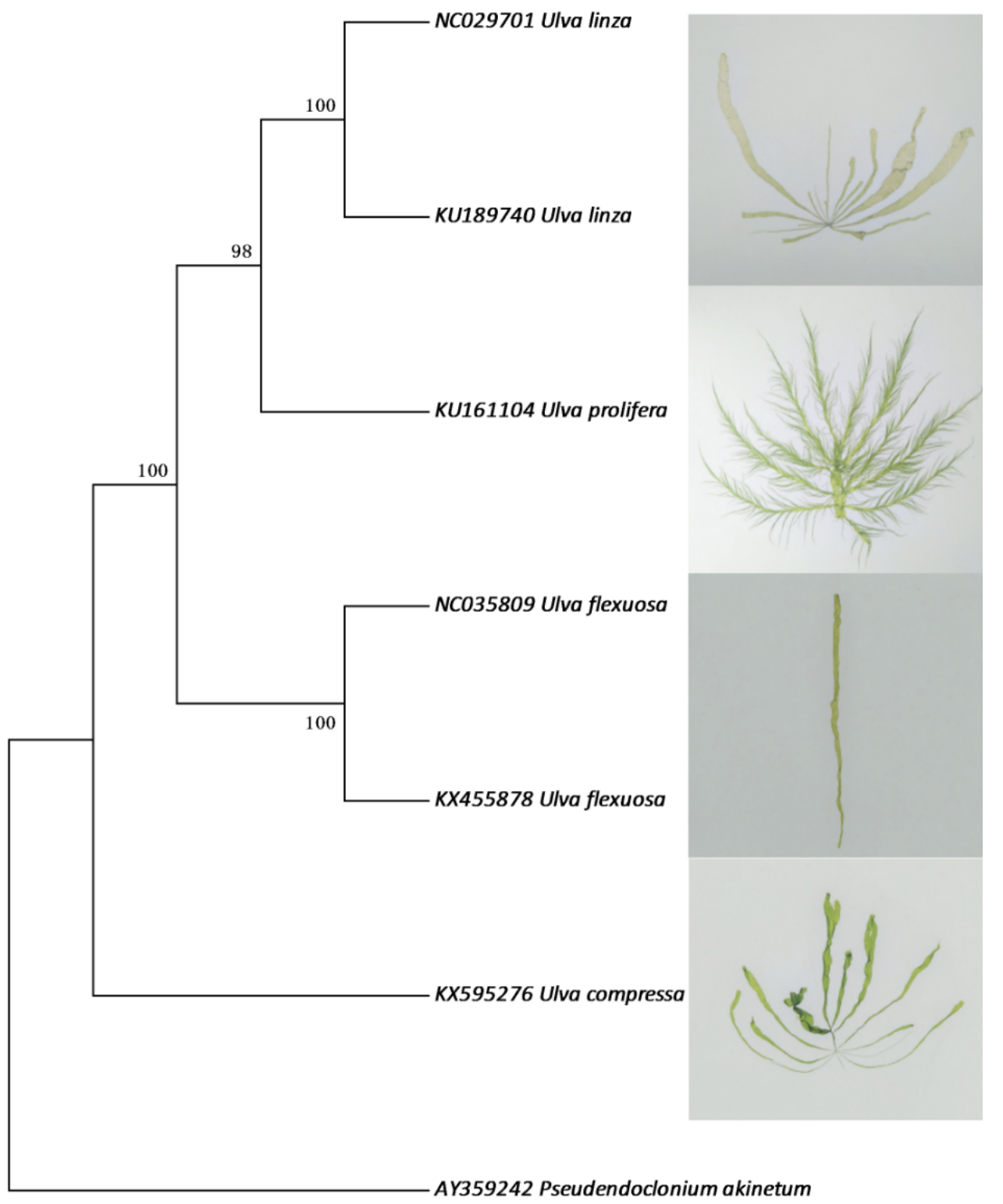

Figure 2. Maximum likelihood phylogenetic tree for free-floating Ulva species based on mitochondrion genomes. 


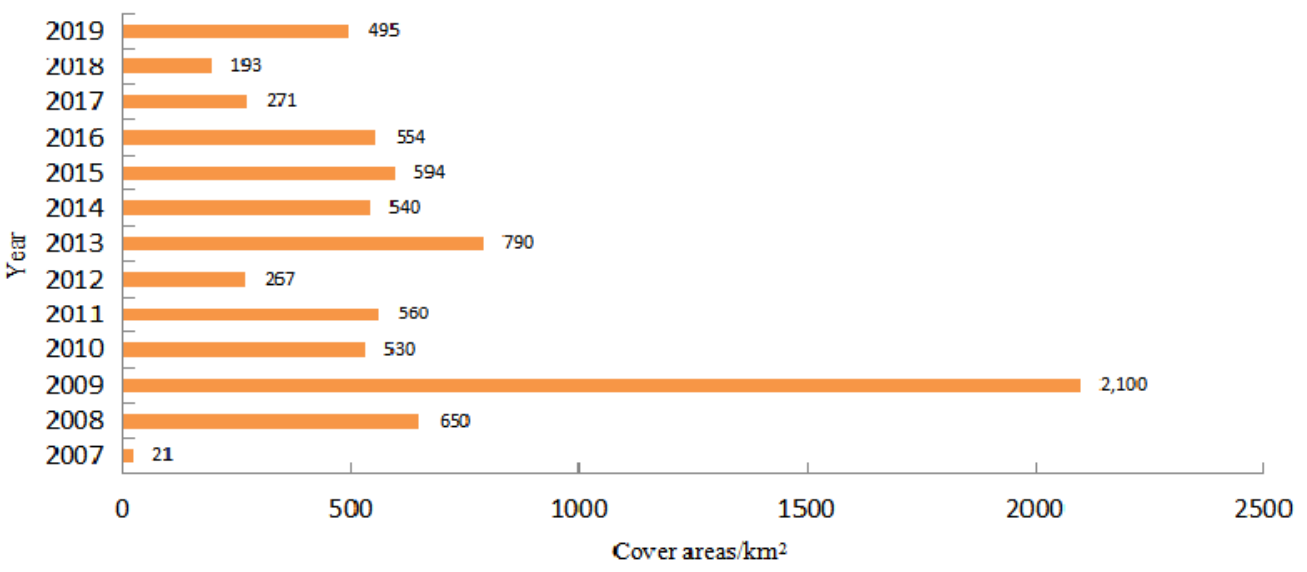

Figure 3. Annual statistics of the largest green tide bloom area in the Southern Yellow Sea of China from 2007 to 2019.

\section{Conclusion}

In this thesis, we analyzed complete mitochondrion genomes of the free-floating Ulva species during the early stage of macroalgae bloom in the Southern Yellow Sea and provided standard morphological pictures of these Ulva species, which will be useful for studying the genetic diversity and phylogenetic history of Ulva species in the Southern Yellow Sea.

\section{Acknowledgments}

This study was financially supported by National Key R\&D Program of China (2016YFC1402103), the Project of Key Laboratory of Marine Ecological Monitoring and Restoration Technologies, M.N.R, (202008; 202012), National Natural Science Foundation of China (41576163), Shanghai Sailing Program (17YF1407900), Luo Zhaorao Science and Innovation Fund (A1200400201328). Also, Jinlin Liu thanks Xiaoqian Yang and Junlin Wu from Shanghai Ocean University for their support.

\section{Disclosure statement}

The authors declare no conflict of interest.

\section{Data availability statement}

The data that support the findings of this study are openly available in National Center for Biotechnology Information (NCBI) at https://www.ncbi.nlm.nih.gov, accession number: NC035809, KX455878, NC029701, KU189740, KX595276, and KU161104.

\section{Author information:}

Liu Jinlin (1996-), College of Marine Ecology and Environment, Shanghai Ocean University, male, born in Nantong, Jiangsu Province, Ph.D., majoring in marine science.

\section{References}

1. Blomster. J, Back. S, Fewer. D.P, Kiirikki. M, Lehvo. A, Maggs. C.A, Stanhope. M.J. Novel morphology in Enteromorpha (Ulvophyceae) forming green tides. Am J Bot. 89(11): p. 17561763 (2002).

2. Merceron. M, Antoine. V, Auby. I, Morand. P. In situ growth potential of the subtidal part of green tide forming Ulva spp. Stocks. Sci Total Environ. 384(1-3): p. 293-305 (2007).

3. Nelson. T.A, Haberlin. K, Nelson. A.V, Ribarich. H, Hotchkiss. R, Van-Alstyne. K.L, Buckingham. L, Simunds. D.J, Fredrickson. K. Ecological and physiological controls of species composition in green macroalgal blooms. Ecology. 89(5): p. 12871298 (2008).

4. Smetacek. V, Zingone. A. Green and golden seaweed tides on the rise. Nature. 504: p. 84-88 (2013).

5. Zhang. J.H, Liu. C.C, Yang. L.L, Gao. S, Ji. X, Huo. Y.Z, Yu. K.F, Xu. R, He. P.M. The source of the Ulva blooms in the East China Sea by the combination of morphological, molecular and numerical analysis. Estuar Coast Shelf Sci. 164: p. 418-424 (2015).

6. Cui. J.J, Zhang. J.H, Monotilla. A.P, Huo. Y.Z, Shi. J.T., Zhao. X.H, Kang. X.Y, He. P.M. Assessment of blooming Ulva macroalgae production potential in the Yellow Sea, China. Phycologia. 58(5): p. 535-541 (2019).

7. Liu. J.L, Zhao. X.H, Kang. X.Y, Zhuang. M.M, Ding. X.W, Zhao. L.J, Wen. Q.L, Zhu. Y, Gu. K, Bao. Q.J, Yang. X.Q, Zhang. J.H, He. P.M. Good news: we can identify Ulva species erupted in the Yellow Sea more easily and cheaply now. Conserv Genet Resour. 12(3): p. 447-449 (2020).

8. Zhao. X.H, Cui. J.J, Zhang. J.H, Shi. J.T, Kang. X.Y, Liu. J.L, Wen. Q.L, He. P.M. Reproductive strategy of the floating alga Ulva prolifera in blooms in the Yellow Sea based on a combination of zoid and chromosome analysis. Mar Pollut Bull. 146: p. 584590 (2019). 
9. Kang. X.Y, Liu. J.L, Yang. X.Q, Cui. J.J, Zhao. L.J, Wen. Q.L, Fu. M.L, Zhang. J.H, He. P.M. The complete mitochondrial genome of a green macroalgae species: Ulva meridionalis (Ulvales: Ulvaceae). Mitochondrial DNA Part B. 5(1): p. 760761 (2020).

10. Xiao. J., Wang. Z.L, Song. H.J, Fan. S.L, Yuan. C, Fu. M.Z, Miao. X.X, Zhang. X.L, Su. R.G, Hu. C.M. An anomalous bi-macroalgal bloom caused by Ulva and Sargassum seaweeds during spring to summer of 2017 in the western Yellow Sea, China. Harmful Algae. 93: p. 101760 (2020).

11. Liu. D.Y, Keesing. J.K, Xing. Q.G, Shi. P. World's largest macroalgal bloom caused by expansion of seaweed aquaculture in China. Mar Pollut Bull. 58: p. 888-895 (2009).

12. Hu. C.M, Li. D.Q, Chen. C.S, Ge. J.Z, MullerKarger. F.E, Liu. J.P, Yu. F, He. M.X. On the recurrent Ulva prolifera blooms in the Yellow Sea and East China Sea. J Geophy Res-Oceans. 115: p. C05017 (2010).

13. Shan. J.Z, Li. J.M, Xu. Z.H. Estimating ecological damage caused by green tides in the Yellow Sea: A choice experiment approach incorporating extended theory of planned behavior. Ocean Coastal Manage. 181: p. 104901 (2019).

14. Wang. H, Wang. G.C, Gu. W.H. Macroalgal blooms caused by marine nutrient changes resulting from human activities. J Appl Ecol. 57(4): p. 766-776 (2020).

15. Zhao. X.H, Yang. X.Q, Zhang. J.H, Wen. Q.L, He. P.M. Karyological observations of Ulva linza chromosomes. Journal of Oceanology and Limnology. Early Online, DOI:10.1007/s00343020-9105-x (2020).

16. Hu. S, Yang. H, Zhang. J.H, Chen. C.S, He. P.M. Small-scale early aggregation of green tide macroalgae observed on the Subei Bank, Yellow Sea. Mar Pollut Bull. 81(1): p. 166-173 (2014).

17. Han. W, Chen. L.P, Zhang. J.H, Tian. X.L, Hua. L, He. Q, Huo. Y.Z, Yu. K.F, Shi. D.J, Ma. J.H, He. P.M. Seasonal variation of dominant free-floating and attached Ulva species in Rudong coastal area, China. Harmful Algae. 28: p. 46-54 (2013).

18. Wang. S.Y, Huo. Y.Z, Zhang. J.H, Cui. J.J, Wang. Y, Yang. L.L, Zhao. Q.Y, Lu. Y.W, Yu. K.F, He. P.M. Variations of dominant free-floating Ulva species in the source area for the worlds largest macroalgal blooms, China: Differences of ecological tolerance. Harmful Algae. 74: p. 58-66 (2018).

19. Zhang. J.H, Huo. Y.Z, Wu. H.L, Yu. K.F, Kim. J.K, Yarish. C, Qin. Y.T, Liu. C.C, Xu. R, He. P.M. The origin of the Ulva macroalgal blooms in the Yellow Sea in 2013. Mar Pollut Bull. 89(1-2): p. 276-283 (2014).

20. Cai. C.E, Wang. L.K, Jiang. T, Zhou. L.J, He. P.M, Jiao. B.H. The complete mitochondrial genomes of green tide algae Ulva flexuosa (Ulvophyceae,
Chlorophyta). Conserv Genet Resour. 10(3): p. 415418 (2018).

21. Pombert. J.F, Otis. C, Lemieux. C, Turmel. M. The complete mitochondrial DNA sequence of the green alga Pseudendoclonium akinetum (Ulvoplayceae) highlights distinctive evolutionary trends in the chlorophyta and suggests a sister-group relationship between the Ulvophyceae and Chlorophyceae. Mol Biol Evol. 21(5): p. 922-935 (2004).

22. Kumar. S, Stecher. G, Tamura. K. MEGA7: Molecular Evolutionary Genetics Analysis version 7.0 for bigger datasets. Mol Biol Evol. 33(7): p. 1870-1874 (2016).

23. Huo. Y.Z, Han. H.B, Shi. H.H, Wu. H.L, Zhang. J.H, Yu. K.F, Xu. R, Liu. C.C, Zhang. Z.L, Liu. K.F, He. P.M, Ding. D.W. Changes to the biomass and species composition of Ulva sp on Porphyra aquaculture rafts, along the coastal radial sandbank of the Southern Yellow Sea. Mar Pollut Bull. 93(12): p. 210-216 (2015).

24. Zhang. J.H, Zhao. P, Huo. Y.Z, Yu. K.F, He. P.M. The fast expansion of Pyropia aquaculture in "Sansha" regions should be mainly responsible for the Ulva blooms in Yellow Sea. Estuar Coast Shelf Sci. 189: p. 58-65 (2017).

25. Zhang. J.H, Shi. J.T, Gao. S, Huo. Y.Z, Cui. J.J, Shen. H, Liu. G.Y, He. P.M. Annual patterns of macroalgal blooms in the Yellow Sea during 20072017. PLOS One. 14(1): p. e0210460 (2019).

26. Liu. J.L, Yang. X.Q, Cui. J.J, Zhuang. M.M, Zhao. L.J, Li. J.Y, Liu. Y.K, Wen. Q.L, Fu. M.L, Zhao. S, Zhang. J.H, He. P.M. Complete chloroplast genome of Ulva meridionalis (Ulvales: Ulvaceae): an extremely fast-growing green macroalgae. Mitochondrial DNA Part B-Resources. 5(2): p. 1390-1392 (2020).

27. Liu. J.L, Yang. X.Q, Li. J.Y, Wen. Q.L, Liu. W, Song. W.P, He. P.M, Zhang. J.H. Research progress on settled mature Ulva prolifera during the outbreak of green tide in the Yellow Sea. Environmental Pollution \& Control. 42(5): p. 614-618 (2020).

28. Shi. J.T, Zhang. J.H, Cui. J.J, Zhao. X.H, Kang. X.Y, Liu. J.L, Wen. Q.L, Yang. X.Q, He. P.M. Artificial hybridization and cross-breeding of Ulva. Journal of Shanghai Ocean University. 28(5): p. 755-764 (2019).

29. Zhuang. M.M, Liu. J.L, Ding. X.W, He. J.Z, Zhao. S, Wu. L.J, Gao. S, Zhao. C.Y, Liu. D.Y, Zhang. J.H, He. P.M. Sargassum blooms in the East China Sea and Yellow Sea: Formation and management. Marine Pollution Bulletin. p. 111845 (2020).

30. Liu. J.L, Xia. J, Zhao. L.J, Gu. K, Kang. X.Y, Ding. X.W, Zhao. X.H, Zhuang. M.M, Zhang. J.H, He. P.M. Species identification of epizoans from Ulva Lactuca in Zhoushan sea area by using the DNA barcode technology. Marine Environmental Science. 39(6): p. 874-879+886 (2020). 